Man and Nature

L'homme et la nature

\title{
Clarissa and the Concept of Tragedy: The Death of Lovelace
}

\section{Hollis Rinehart}

Volume 2, 1984

URI : https://id.erudit.org/iderudit/1011810ar

DOI : https://doi.org/10.7202/1011810ar

Aller au sommaire du numéro

Éditeur(s)

Canadian Society for Eighteenth-Century Studies / Société canadienne d'étude du dix-huitième siècle

ISSN

0824-3298 (imprimé)

1927-8810 (numérique)

Découvrir la revue

Citer cet article

Rinehart, H. (1984). Clarissa and the Concept of Tragedy: The Death of Lovelace. Man and Nature / L'homme et la nature, 2, 37-47.

https://doi.org/10.7202/1011810ar
Résumé de l'article

Clarissa de Richardson fait apparaître deux théories de la tragédie qui sont partiellement opposées : la théorie didactique qui véhicule un enseignement moral moyennant l'attrait d'une histoire qui plait, et la théorie affective, d'origine aristotélienne, selon laquelle le public doit être amené à éprouver pitié et crainte. La fin de la vie de Clarissa et sa mort édifiante illustrent la théorie didactique, tandis que la mort de Lovelace excite la crainte du spectateur, si elle ne réussit pas à susciter sa pitié, et correspond donc davantage à l'idée moderne du tragique.
Copyright (C Canadian Society for Eighteenth-Century Studies / Sociéte canadienne d'étude du dix-huitième siècle, 1984
Ce document est protégé par la loi sur le droit d'auteur. L'utilisation des services d'Érudit (y compris la reproduction) est assujettie à sa politique d'utilisation que vous pouvez consulter en ligne.

https://apropos.erudit.org/fr/usagers/politique-dutilisation/ 

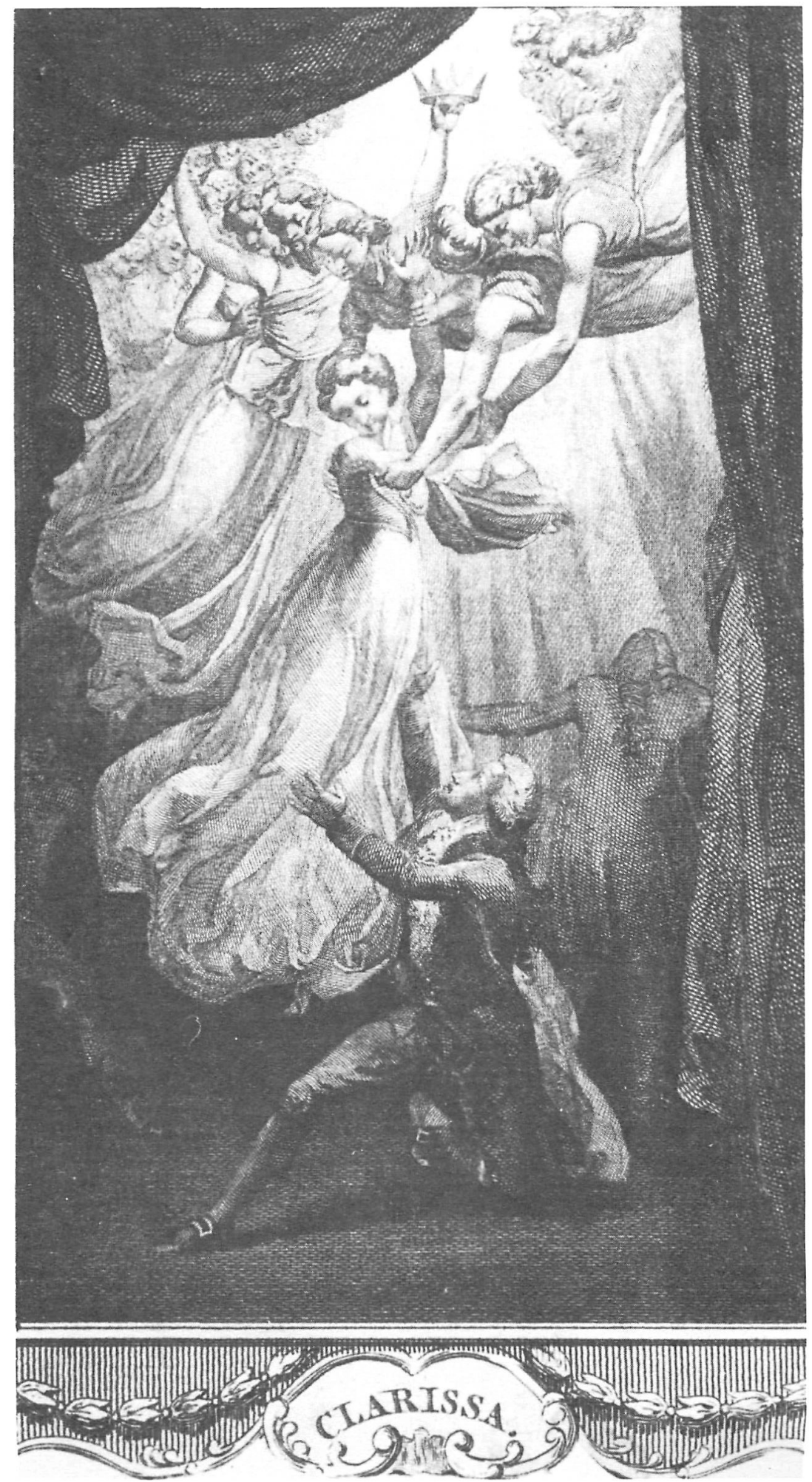


\section{CLARISSA AND THE CONCEPT OF TRAGEDY:}

THE DEATH OF LOVELACE

Hollis Rinehart

This paper begins from the perception--a personal one, but tested over a period of several years by conversations with students--that the death of Lovelace is in many ways a more satisfactory ending to Clarissa than is the death of Clarissa herself. No doubt this statement would be disappointing to Richardson, but it is he who must take the blame, for failing to resolve the contradictions inherent in his own theory of tragedy. It may seem odd to speak of Richardson as having a "theory" of tragedy. A diffident man, he rarely offers theoretical statements, and when he does usually takes refuge behind the words of others, as for example in the passages from Addison and Rapin which he quotes in the Postscript to Clarissa. These passages are revealing, however, for they show Richardson to have been caught in the conflict between two current views of tragedy, to both of which he subscribed. These have been termed by Eric Rothstein the "fabulist" and the "affective,"l and may be described as follows. The fabulist theory is the time honored view that tragedy should provide a moral example or fable in a disguised and sweetened form. This is the view familiar to us from Sidney's Apology for Poetry: the poet comes to us

with a tale which holdeth children from play, and old men from the chimney corner. And, pretending no more, doth intend the winning of the mind from wickedness to virtue: even as the child is often brought to take most wholesome things by hiding them in such other as have a pleasant taste.

Clearly this was Richardson's view of the function of poetry, since he never tires of repeating, in his correspondence and elsewhere, that all his works have a moral purpose, and that Clarissa is intended as an example. 
The affective view is equally venerable, going back at least to Aristotle. This is the view that tragedy is primarily distinguished by its emotional effects, namely pity and fear, together with a catharsis of these emotions. According to this view, it is the job of the tragedian simply to arouse men's emotions; this in itself, however, can have a moral effect, by softening men's hearts and making them more susceptible to pity for others and to fear of wrongdoing. 3 These two conceptions of tragedy, it will be seen, are not necessarily in conflict, and in fact the two may be found slumbering peacefully side by side down through the ages. Even in Sidney, for example, we find the following description of tragedy:

Tragedy openeth the greatest wounds, and showeth forth the ulcers that are covered with tissue; [it] maketh kings fear to be tyrants, and tyrants manifest their tyrannical humours; [and] with stirring the affects of admiration and commiseration, teacheth the uncertainty of this world, and upon how weak foundations gilden roofs are builded.

In Richardson's time, this conception of tragedy had emerged with new vigor. According to Rothstein, its revival in England began with the translation of Rapin's Reflections on Aristotle's Treatise of Poetry, in 1674. Curiously, the translator was Thomas Rymer, who was the leading champion of the fabulist view--an indication of the extent to which it was possible for these two theories to flourish side by side. The new (or revived) view was quickly taken up by numerous critics, among whom the most influential were Dryden and Addison--and of course it is Rapin and Addison whom Richardson cites in the Postscript to Clarissa.

Again, that Richardson sincerely held this view of the function of tragedy cannot be doubted. Apart from his citation of Rapin and Addison, in his correspondence he speaks frequently of the need to arouse the emotions. Writing to Lady Bradshaigh in defense of the unhappy ending of Clarissa, he argues, "Terror and Pity and Fear are Essentials in a Tragic Performance," which Clarissa is. "Indeed, Madam, I could not think of leaving my Heroine short of Heaven: Nor that I should do well if I punished not so premeditated a Violation; and thereby made Pity on her Account, and Terror on his, join to complete my great End, for the sake of Example and Warning." 5 Here the two aims, of arousing emotion and of setting an example, are completely blended. Another passage in the same letter, describing the effects of Shakespeare's tragic scenes, suggests how this was to be accomplished. "The Representations of those Scenes," he says, "must have been mismanaged, if they did not soften and mend the Heart."6 Richardson's own susceptibility to such emotional scenes can be inferred from a passage in a letter to Aaron Hill, in which he describes the effects of merely having attempted to read the manuscript of Hill's book, The Art of Acting, which Richardson printed in 1746. "I endeavoured to follow you in your wonderful Description of the Force of Acting, in the Passion of Joy, Sorrow, Fear, Anger, \&c. And my whole Frame, so nervously affected before, was shaken by it: I found, in short, such Tremors, such Startings that I was unable to go thro' it."7 He regarded the power of raising emotion to be the sign of the true poet. In another letter to Lady Bradshaigh he cites the motto of Spectator 40, as later translated by Pope from Horace, which he was to cite in the Postscript of Clarissa. 


\begin{abstract}
Yet, lest you think I rally more than teach Or praise malignly Arts I cannot reach, Let me for once presume t'instruct the Times To know the poet from the Man of Rhymes. ' Tis he, who gives my Breast a thousand Pains Can make me feel each Passion that he feigns; Enrage, compose, with more than Magic Art With Pity and with Terror tear my Heart; And snatch me o'er the Earth, or thro' the Airr, To Thebes, to Athens, when he will or where.
\end{abstract}

Between these two conceptions of tragedy there is of course no necessary contradiction, but neither is there any necessary dependency. As long as they remain theories, they can lie down together quietly, side by side. For the practicing artist, however, there are pitfalls involved in holding both views simultaneously, and unfortunately Richardson fell straight into one of them. The fabulist view requires that the characters be exemplary, while the affective view requires that we sympathize with them, and these two aims may be in conflict. From a modern point of view, Richardson does not pay enough attention to the reactions of his readers. Instead of applying himself to raising pity and fear to their highest pitch, and letting these emotions regulate by themselves the moral sentiments of his audience, he felt it necessary to intervene, and teach his moral lessons directly, with dire consequences for his tragic effect, at least in the case of Clarissa. Specifically, he ignored the warning of Aristotle, in chapter thirteen of the Poetics, that the tragic hero should be neither an extremely good man nor an extremely bad one, but rather someone in between, someone "like ourselves." Only in this way can the tragedian hope to raise pity and fear, for "pity is occasioned by undeserved misfortune, and fear by that of one like ourselves." 9 This formula describes Clarissa well for approximately three-quarters of the novel, but in the last quarter something dramatic (or rather, un-dramatic) happens to her--she ceases to be someone "like ourselves," and becomes an angel. This observation can be supported not only by countless references to her as an angel, 10 but by the attitude of the other characters to her: Wyerly, the suitor whom Clarissa rejected for his atheistical attitudes, renews his suit, loves her "to adoration," and, obviously reformed, prays to God to bless and protect her; ${ }^{11}$ Belford cannot bear to be out of her company for fear of missing some improving remark; and Lovelace, dying, prays to her as to a saint. Even her body is not corrupted or disarranged by the removal from London to Harlowe Place--the same sweet smile remains (IV, 398). All that is missing is an odor of violets.

The most vivid picture of Clarissa as an angel, however, occurs, with telling irony, in the dream which Lovelace has after Clarissa has escaped from him for the second and last time. In this dream, he imagines himself about to fight a duel with Colonel Morden, when Clarissa intercedes, asking them to spare one another, for she does not want to lose either of those who are so dear to her. Charmed with this "sweet mediation," Lovelace seeks to clasp her in his arms, when suddenly an angelic form, clad in transparent white, descends in a cloud and lifts Clarissa up into a firmament crowded with seraphim. Lovelace seizes her robe in hopes of detaining her, but she vanishes, and he is left holding her azure robe, thickly embossed with silver stars. Suddenly the floor opens under him, and he drops 
into a bottomless pit, falling over and over, until he awakes in a panic, "as effectually disordered for half an hour, as if my dream had been a reality" (IV, 136). In 1784 this passage was chosen by Thomas Stothard as the subject of one of thirty-four illustrations to Clarissa which he executed for the Novelist's Magazine. The illustration is interesting as showing the importance of this vision of Clarissa to the readers of Stothard's time, less than thirty years after the death of Richardson. The illustration is interesting also for the changes made by Stothard. For example, in the dream the central figure is the angel in white, who "encircling" Clarissa ascends with her to the region of seraphim; in the illustration, however, Clarissa is the central figure in white, and is supported by a group of angels, none of whom is especially prominent. In the illustration, also, a heavenly crown is prepared for Clarissa, which is missing in the dream. And most markedly, of course, Lovelace has not yet sunk into the pit below her. The effect is to further emphasize Clarissa's angelic quality.

The trouble with Richardson's strategy is that through it Clarissa is placed beyond our sympathy--it is impossible to pity a saint. Doubtless this was Richardson's intention. Her death and transfiguration are to be seen as a reward for her suffering, and the catharsis of our genuine pity and fear aroused for her earlier in the book. However, this catharsis should not be achieved at the cost of the complete destruction of her character. The difference between this bloodless saint and the spirited girl whom we have known and loved so well during the preceding three quarters of the book can be seen vividly on the few occasions when she relapses into humanity, as in her cutting replies to her uncles' heartless letters (IV, 101-102, 105-107), or in her occasional expressions of weariness and despair. "I am very much tired and fatigued," she writes to Anna Howe, "with--I don't know what--with writing, I think--but most with myself, and with a situation I cannot help aspiring to get out of, and above!" (IV, 103) And again, in a letter to Mrs. Norton, she admits to being "offended" by her family's haughty treatment, and describes herself as "petulantly perverse." "Poor mistaken creature! Unhappy self-deluder! that finds herself above nothing! Nor able to subdue her own faulty impatience!" (IV, 194-195).

This is the right note with which to arouse pity and fear. But in general Richardson is unrelenting in his efforts to make Clarissa appear as magnanimous as possible, even in her pathetic efforts at self-defense and maidenly modesty. In a ruse to prevent Lovelace's visiting her at Mrs. Smith's, she writes him a letter, in which she says that she is going to "her father's house," and promises to meet him there, "if it be not your own fault," and to send him a letter when she arrives (IV, 157). Of course it is all allegory: she refers to her father who is in heaven, and the letter she promises him is delivered after her death. It is a clever allegory, as close as she ever comes to a lie, and it succeeds in throwing Lovelace off the trail. However, Richardson cannot let it rest at that, but must have it that the letter shows both "piety" and "charity" as well as "invention" (IV, 213). Again, part of Clarissa's reason for ordering her own coffin is that she has "a man, not a woman, for my executor--and think you that I will leave to his care anything that concerns my own person?" (IV, 180) This is touching; but again Richardson construes it 
into something grander: "Here's presence of mind; here's tranquility of heart, on the most affecting occasion! This is magnanimity indeed!" "Couldst thou," writes Belford to Lovelace, "or could I, with all our boisterous bravery, and offensive false courage, act thus?" (Ibid) The answer is obviously intended to be "no," but it does not strain our credulity to imagine Lovelace or Belford, or even quite a few of Richardson's readers, ordering their own coffins. As Ian Watt says of Clarissa on another occasion, it is somewhat difficult to "muster the proper awe."

With Lovelace, however, Richardson did not make the corresponding mistake--that is, while Clarissa becomes an angel, Lovelace never becomes a devil, although Clarissa frequently calls him one. I would not go so far as John Carroll, who suggests that he might be considered a tragic herol3--the memory of his transgressions during the rape scenes can never be erased so thoroughly as that--but it seems clear that he is not a completely bad man, not so much as completely to lose our sympathy, or at least our interest in him--what Aristotle calls "the human feeling."14 I am not referring here to his good looks or to his intellectual powers, to his way with words, or even to his skill with the sword--these are all morally indeterminate qualities, neither good nor bad in themselves, but only in the way that they are used. Nor do I refer to his reputed generosity towards his tenants; this behavior is so remote from the events of the novel as to make virtually no impression on us. Rather I refer to qualities which are dramatically depicted in the last quarter of the novel, namely, his courage, his ability to feel remorse, and his ability to make a (relatively) honest mistake.

Let us go back for a moment, however, to the rape episode, in order to define more clearly the potentialities of Lovelace's character. Consider the following passage: Lovelace, under pretence of placing Clarissa under the protection of hs kinswomen, Lady Betty Lawrence and Miss Montague, has enticed Clarissa back to Mrs. Sinclair's house; now, by means of a letter from the supposed Lady Betty, he informs her that she will be left alone in the house overnight.

It seems, when she read the billet--Now indeed, said she, am I a lost creature! 0 the poor Clarissa Harlowe!

She tore off her head-clothes; inquired where $I$ was: and in she came, her shining tresses flowing about her neck; her ruffles torn, and hanging in tatters about her snowy hands; . . . Down sunk she at my feet, as soon as she approached me; her charming bosom heaving to her uplifted face; and clasping her arms about my knees, Dear Lovelace, said she, if ever--if ever--if ever--and, unable to speak another word, quitting her clasping hold, down prostrate on the floor sunk she, neither in a fit nor out of one.

I was quite astonished. All my purposes suspended for a few moments, I knew neither what to say, nor what to do....

I lifted her, however, into a chair; and in words of disordered passion, told her, all her fears were needless: wondered at them: begged of her to be pacified: besought her reliance on my faith and honour: and revowed all my old vows, and poured forth new ones.

(III, 192-93) 
In this truly horrifying passage, we see a man divided against himself. On the one hand, there is the undoubted sexual sadist, who can see a woman who is under his protection sink down on her knees and implore his pity, even in a manner declare her love for him ("Dear Lovelace, said she, if ever--if ever--" if ever what? if ever you loved me, or if ever you hoped to win my love?), and yet persist in his plan to drug and rape her, all the time noting her "charming bosom heaving to her uplifted face." On the other hand, what are we to make of his "words of disordered passion," in which he assures her that "all her fears were needless," and his renewal of his old vows, and vowing of new ones? I suggest that these sentiments also are perfectly sincere, and that in some strange way Lovelace enjoys both tormenting Clarissa and comforting her. These traits may seem less contradictory when we consider that both are aspects of power over the woman. Lovelace wants both the power to destroy and the power to heal. He wants to be all in all to the woman of his choice. As he says in describing what he wants in a wife,

I would have the woman whom I honour with my name, if ever I confer this honour upon any, forego even her superior duties for me. I would have her look after me when I go out, as far as she can see me, as my Rosebud after her Johnny; and meet me at my return with rapture. I would be the subject of her dreams, as well as of her waking thoughts. I would have her think every moment lost, that is not passed with me: sing to me, read to me, play to me when I pleased; no joy so great as in obeying me (II, 416).

As one of my students once remarked, "he doesn't want a wife, he wants a dog!" And this is true. He does not want an equal relationship with another human being, he wants the sort of dependence which can only be found with a creature of another species.

However, without going into the psychopathology of such a character, I think we can agree that such a character is possible, and that he is in a fairly desperate state. What prevents the two contradictory halves of such an undisciplined character from simply tearing him apart? I suggest that it is his carefully cultivated pose of a witty rake which enables him to reconcile these contradictory elements, or at least to keep them in a relatively stable solution. The lighthearted rake need not take anything too seriously. He can flit back and forth from one attitude to the other like a butterfly between blossoms, thus disguising from the world, and even perhaps from himself, how seriously he feels about things. But this "golden dream," as Clarissa calls it, of having the best of both worlds, "cannot last long." Reality, in the shape of a very determined nineteenyear-old girl, comes crashing in and brings it to the ground. The collapse occurs when Lovelace discovers that he does not have his imagined powers. It begins immediately after the rape, when he discovers that Clarissa has not been humbled by it. It continues when he finds that he is unable to repeat his rape--Clarissa will kill herself rather than submit. Things get still worse when Clarissa escapes for a second time from Mrs. Sinclair's, and worse yet when his confederates, out of control, find her and commit her to prison. Lovelace rescues her from that, but by now he is shaken, and does not dare approach her. Instead he appears at Colonel Ambrose's ball, where he seeks Anna Howe's intervention. 
His behavior at the ball is a masterpiece of rakishness, bewitching everyone except Anna (and Clarissa, when she hears about it). Anna writes, "He entered with an air so hateful to me, but so agreeable to every other eye" (IV, 19). She calls him a "sycophant," "impudent," possessing "superlative assurance" and "impenetrable effrontery" (IV, 20, 23). Perhaps most telling, "it seems to me that nothing can touch him for half an hour together" (IV, 25). This is the mask which Lovelace successfully presents to the world. Anna, however, and especially Clarissa, see through him. When told of his visit, Clarissa writes, "Poor wretch! I pity him, to see him fluttering about; abusing talents that were given him for excellent pur-poses; taking inconsideration for courage . . " (IV, 29). It may be doubted, however, whether Lovelace fools himself any better than he does Clarissa. In desperation he comes to visit her at Mrs. Smith's. Forewarned by Belford, Clarissa has gone away, but Lovelace amuses himself by playing the fool with the Smiths, pretending that he will extract the servant's tooth with his penknife, and stepping behind the counter to sell a pair of gloves to a passerby. This time even Belford is shocked at his levity (IV, 143). It appears that the pose of a carefree rake, however it may impress casual bystanders, like the Smiths and their simple-minded servant Joseph, will not impress those whom Lovelace cares about most.

The final blow, however, is given by Clarissa's death, which puts her forever beyond his power. At this point Lovelace becomes violent; he threatens to seize Clarissa's body, have her disembowelled, and her heart preserved in spirits. Her body will be embalmed and laid in his family vault, between his father and mother. Her bowels will be sent down to her family, since they have none of their own (IV, 376). He has actually set out with a surgeon for this purpose, when he is intercepted. Mowbray writes to Belford, "get the lady buried as fast as you can; and don't let him know where" (IV, 374). The next stage is madness. Lovelace is confined, bled, dosed, manacled and whipped. He describes his torments in a letter to Belford:

I had no distinct ideas, but of dark and confused misery: it was all remorse and horror indeed! Thoughts of hanging, drowning, shooting; then rage, violence, mischief, and despair took their turns with me. My lucid intervals still worse, giving me to reflect upon what I was the hour before, and what I was likely to be the next, and perhaps for life--the sport of enemies! the laughter of fools! and the hanging-sleeved, go-carted property of hired slaves; who were perhaps to find their account in manacling, and (abhorred thought!) in personally abusing me by blows and stripes:

Who can bear such reflections as these? (IV, 441).

At this point the question arises, what do we wish for such a man? There is no question of pitying him, for "pity is occasioned by undeserved misfortune," and Lovelace has certainly deserved all his misfortunes, as he would be the first to admit. There may be fear, however, since fear is for one "like ourselves," and Lovelace seems to have gained rather than lost humanity by his sufferings. Fear in this case would have to take the form of fearing either that he might do something unworthy of himself, such as disembowelling Clarissa's body, or that he might be punished beyond his 
just deserts. What he himself most fears, it is clear, is permanent madness. Could we wish this on him, that he should become that thing he fears, "the hanging-sleeved, go-carted property of hired slaves"? To do so would be to reduce him to something less than human. On the other hand, we cannot wish him a complete recovery, "else," to paraphrase Othello, "he'll undo more women." The best course seems to be somewhere in between, namely, that he should recover his health, but not his peace of mind, and that he should then die. In wishing him to die, however, we are not, I believe, wishing him further punishment--he has been punished as badly as he can be--but rather an end to his sufferings. In other words, we wish his death for his own sake as much as for Clarissa's. Hence his death must be one with which he himself can be satisfied, not a death by gangrene, after breaking his leg in a fall, like Mrs. Sinclair's, nor even after a lingering illness, like Belton's. Lovelace's death must be an active one, in a cause which he can believe in, whether we do or not.

Whether or not this was Richardson's reasoning, this is the kind of death he has provided for Lovelace, in his duel with Colonel Morden. Death by duelling is highly appropriate, of course, because Lovelace has maintained his power over Clarissa all along by the threat of a duel with her brother James, whom (for some reason) she feels obliged to protect. As several critics have pointed out, the book begins with a duel, and it ends with a duel. Furthermore, this duel is for a cause that Lovelace can believe in, for although he fully accepts his guilt in Clarissa's seduction and death, he cannot grant anyone else the right to reproach him more than he does himself. As he writes to Belford,

I can't bear to be threatened, Jack. Nor shall any man, unquestioned, give himself airs in my absence, if $I$ know it, that shall make me look mean in anybody's eyes: that shall give my friends pain for me: that shall put them upon wishing me to change my intentions, or my plan, to avoid him. Upon such despicable terms as these, think you that I could bear to live? (IV, 515)

These are sentiments which, I think, although we may not precisely share, at least we can respect. At the same time, we are carefully preserved from seeing Lovelace's actions as in any way heroic by Clarissa's frequently expressed horror of duelling, and her fear that some member of her family will attempt to revenge her death. Nor is Lovelace's antagonist, Colonel Morden, any knight in shining armor. Lovelace accuses him of being himself "a man of gallantry" (IV, 220), and Belford describes him as "far from being a faultless man" (IV, 242). His attitude toward himself is clearly expressed in his comment on Clarissa's strictures against duelling: "Meantime, I will own that I think my cousin's arguments unanswerable. No good man but must be influenced by them. But, alas! sir, who is good?" (IV, 464) A clearer example of Aristotle's man "not pre-eminently good or just" ${ }^{15}$ could hardly be found.

Thus Lovelace has the satisfaction of being slain by one not morally superior to himself, at least not in kind, but one like himself, on terms which he fully understands and accepts. "There is a fate in it!" he says, after his mortal wound, "--a cursed fate!--or this could not have been! But be ye all witnesses that I have provoked my destiny, and acknowledge 
at I fall by a man of honour" (IV, 529). Indeed, it is in his death that

lace most nearly approaches the description of a tragic hero. Duelling

- not fall into the category of a "vice or depravity," but of an "error in judgement," which is the way the tragic hero's downfall must be brought about if he is to maintain our sympathy. Lovelace's error, however, extends one step further--he is sure he will win. This again puts an effective check upon our sympathy, since he knows his cause is unjust. Nor is the picture of his actual death an encouraging one. After his wound, "Contrary to all expectation," writes his valet, De la Tour, "he lived over the night: but suffered much, as well from his impatience and disappoiptment as from his wounds; for he seemed very unwilling to die" (IV, 530).

We must not fail to say something about Lovelace's final words, again as reported by his valet.

Blessed--said he, addressing himself no doubt to Heaven; for his dying eyes were lifted up. A strong convulsion prevented him for a few moments saying more, but recovering, he again, with great fervour (lifting up his eyes and his spread hands), pronounced the word blessed. Then, in a seeming ejaculation, he spoke inwardly, so as not to be understood: at last, he distinctly pronounced these three words,

\section{LET THIS EXPIATE:}

And then, his head sinking on his pillow, he expired, at about half an hour after ten (IV, 530).

There can be no doubt about the sincerity of these final words; the question is, will it win him entrance to heaven? There is something almost blasphemous about the egotism of proposing that his own loss of life should compensate for that of Clarissa--but then, what more can he do, but die? De la Tour, a good Catholic, would no doubt be shocked to learn that Lovelace was not addressing Heaven, but an earthly lady. But what could he know of the subtleties which are possible between a Protestant and his God, who are in direct communication? Of the commentators whom I have read, most seem to think that there is no possibility of Lovelace's being saved. 17 My own feeling is that Richardson has carefully contrived to leave the issue in doubt. All the characters in the book speak of it in this way. Colonel Morden, "cooly reflecting upon his beloved cousin's reasonings against duelling; and upon the price it had too probably [my emphasis ] cost the unhappy man... wishes he had more fully considered those words in his cousin's posthumous letter: 'If God will allow him time for repentance, why should you deny it him?'"(IV, 550-51). The ambiguity surrounding Lovelace's death can be seen more clearly, I think, if we compare it with that of Don Giovanni, in Mozart's opera. Three times the stone dinner guest asks Don Giovanni to repent, and each time the Burlador of Sevilla responds with a resounding "no" before he is carried of $f$ to eternal damnation. No doubt it would be most unsatisfactory to see Lovelace ascend to Heaven, accompanied by crowds of angels; on the other hand, to send him straight to Hell might raise doubts about the efficacy of the prayers of Saint Clarissa. 
NOTES

1 Eric Rothstein, "English Tragic Theory in the Late Seventeenth Century," ELH, 29 (1962), 306-23. See also John A. Dussinger, "Richardson's Tragic Muse," Philological Quarterly, 46 (1967), 18-23.

2 An Apology for Poetry, ed. Forrest G. Robinson (New York: Library of Liberal Arts, 1970), p. 38.

3 Alternatively, the discharge of pity and fear may prevent dangerous excesses of these emotions from building up in the audience (the homeopathic view). These two interpretations of the moral effect of pity and fear seem to be interchangeable. Both are put forward by Rapin in the passage cited by Richardson in the Postscript to Clarissa. (Clarissa, ed. John Butt [New York: Everyman's Library, 1968] IV, $555-56$. )

Apology, p. 45.

Selected Letters of Samuel Richardson, ed. John Carroll (Oxford: Clarendon Press, 1964), pp. 104-105.

Letters, p. 105.

$7 \quad$ Letters, p. 74 .

8 Letters, p. 96; Clarissa, IV, 555.

9 Poetics, 1453a, trans. Ingram Bywater, in The Works of Aristotle, (Oxford: Clarendon Press, 1952), Volume XI.

10 See the remarks of the parish priest who administers the last sacrament to Clarissa: "He stayed with her about half an hour; and when he came down, with his face turned aside, and a faltering accent: 'Mrs. Smith, said he, you have an angel in your house.'" (IV, 174). Lovelace, of course, refers to Clarissa from the start as an "angel," "goddess," "divine," etc. (I, 144-52, passim). It is one of the ironies of the book that these frigid cliches turn out to be literally true.

11 Clarissa, IV, 202-204. Hereafter cited in the text by volume and page number.

12 The Rise of the Novel (Berkeley: University of California Press, 1962), p. 212 .

13 "Lovelace as Tragic Hero," University of Toronto Quarterly, 42 (1972), 14-25.

14 Poetics, 1453a. 
15 Poetics, 1453a.

16 Richardson's emphasis, added in the third edition.

17 See, e.g., John Carroll, "Lovelace as Tragic Hero," p. 25; T.C. Duncan Eaves and Ben Kimpel, Samuel Richardson: A Biography (Oxford: Clarendon Press, 1971), p. 255. But see also Margaret Anne Doody, A Natural Passion (Oxford: Clarendon Press, 1974), pp. 181-82. 